\title{
Polar Regions (2019)
}

\author{
Stefan Kirchner*
}

The polar regions, both the Arctic and Antarctica, are characterized by harsh climates and very low population densities, with Antarctica only being a temporary home for researchers and other staff. Especially the Arctic is undergoing rapid changes, due to both climate change and globalization. Increasing economic activities in the Arctic, such as tourism or the extraction of hydrocarbons, lead to increasing risks for disasters which can affect both local residents, including the many indigenous communities of the Arctic, as well as visitors. ${ }^{1}$ At the time of writing, in late January 2020 , the rapid spread of the novel coronavirus from the Chinese city of Wuhan has already had a serious economic impact on the tourism industry in the continental European Arctic. Faced with new kinds of threats, decision-makers on different levels have to respond to the risk of disasters in a challenging climatic and economic environment.

Often, such responses will require international cooperation. The eight Arctic states, Canada, the United States of America (with regard to Alaska), Denmark (with regard to Greenland), Iceland, Norway, Sweden, Finland and the Russian Federation, are parties to the Arctic Search and Rescue Agreement (Arctic SAR Agreement), ${ }^{2}$ which has provided a framework for cross-border cooperation since it entered into force in 2013. The Arctic SAR Agreement had been created under the auspices of the Arctic Council, the key forum for international cooperation in the Arctic. ${ }^{3}$ The importance of cross-border cooperation can also be seen in the recent work of the Arctic Council concerning the Agreement on Cooperation on Marine Oil Pollution Preparedness and

* Associate Professor of Arctic Law, University of Lapland.

1 For an overview over risks to human safety in the Arctic see e.g. Stefan Kirchner, 'Historical Perspectives of the Environmental and Human Security in the Arctic', in Satu Uusiautti and Nafisa Yeasmin (eds), Human Migration in the Arctic - Facets to the Past, Present, and Future (Palgrave Macmillan 2019) 13-30.

2 Agreement on Cooperation on Aeronautical and Maritime Search and Rescue in the Arctic (2011) <https://oaarchive.arctic-council.org/bitstream/handle/11374/531/EDOCS -3661-v1-ACMMDKo7_Nuuk_2011_SAR_Search_and_Rescue_Agreement_signed_EN_FR _RU.PDF? sequence $=5$ \& \&isAllowed $=\mathrm{y}>$ last accessed (as any subsequent URL) on 1 February 2020.

3 On the role of the Arctic Council for the development of international treaties see e.g. Timo Koivurova, Pirjo Kleemola-Juntunen and Stefan Kirchner, 'Chapter 4: Arctic Regional Agreements and Arrangements', in Karen Scott and David VanderZwaag (eds.), E E Research Handbook on Polar Law (Cheltenham: Edward Elgar 2020, forthcoming). 
Response in the Arctic (MOSPA) ${ }^{4}$ but also in more recent work such as that of the Arctic Council's Task Force on Arctic Marine Cooperation and the Task Force on Improved Connectivity in the Arctic (TFICA). The latter is concerned with the problem of the limited infrastructure in the Arctic. ${ }^{5}$

For a long time, cooperation in the Arctic was characterized by the relative absence of political disputes and a concentration on regionally relevant issues, crossing political divides in order to achieve tangible results for the people who live in the Arctic. Such cooperation appears to be more necessary than ever because the challenges caused by anthropogenic climate change, which affects the Arctic more than any other part of the globe, require a common response. At the 2019 Arctic Council Ministerial Meeting in Rovaniemi, Finland, the current political positions of the United States and the Russian Federation, in particular with regard to climate change, led to a failure to adopt a complete declaration. The past experience with the work of the Arctic Council indicates that this might only have been reflective of the current domestic political situation in these countries and that the overall commitment to international cooperation in the Arctic remains in place. In place of a declaration, the 2019 Arctic Council Ministerial Meeting ended with a statement from the ministers and a statement by the chair, ${ }^{6}$ which also mentioned the role of local communities.

Local, and in particular indigenous, communities in the Arctic are often affected by outside factors, for example the mining or tourism industries. In particular the tourism industry, though, has increasingly shown an ability for self-regulation and adaptation to the safety needs in the harsh Arctic and Antarctic environments. Tour operators, such as the Association of Arctic Expedition Cruise Operators (AECO) and the International Association of Antarctica Tour Operators (IAATO) have published guidelines for cruise operations in the Arctic ${ }^{7}$ and in the waters off Antarctica. These guidelines

4 Agreement on Cooperation on Marine Oil Pollution Preparedness and Response in the Arctic (2013) <https://oaarchive.arctic-council.org/bitstream/handle/11374/529/EDOCS -2068-v1-ACMMSEo8_KIRUNA_2013_agreement_on_oil_pollution_preparedness _and_response_signedAppendices_Original_130510.PDF?sequence $=6 \&$ \&isAllowed $=\mathrm{y}>$.

5 On infrastructure challenges in the Arctic and the importance of reliable mobile telecommunication services see e.g. Stefan Kirchner, 'Mobile Internet Access as a Human Right: A View from the European High North', in Kamrul Hossain, Mirva Salminen and Gerald Zojer (eds), Enablement besides Constraints: Human Security and a Cyber Multi-disciplinary Framework in the European High North (Palgrave Macmillan 2020, forthcoming).

6 <https://arctic-council.org/images/PDF_attachments/Rovaniemi-Statement-from-the -chair_FINAL_840AM-7MAY.pdf $>$.

7 AEco, Aeco's Guidelines for Expedition Cruise Operations in the Arctic (2019), <https:// www.aeco.no/wp-content/uploads/2019/12/2019-operational-guidelines-final-2.pdf>. 
are to be understood as an addition to binding national and international standards, not as a replacement and are meant to protect the fragile polar environment as well as local residents (in the Arctic) and visitors. Their focus is largely on the reduction of disaster risks, ranging from the risk of small damage to the local plant life to the safety of ships and boats, such as zodiacs, both during visits and in the planning stages. Through the work of AECO and IAATO, practical knowledge is infused into the process of creating soft law standards which enhance safety in polar regions and which contribute to the reduction of disaster risks. This benefits in particular visitors to polar regions, such as tourists, who might have little or no prior experience of the everyday risks one can encounter in the Arctic or Antarctica. This is an ongoing process and the tourism associations continuously develop their respective guidelines and provide information material online.

One 2019 incident in Norway should give everybody involved in DRR in the Arctic pause: on 23 March 2019, the cruise vessel 'Viking Sky' lost power off the coast of Southern Norway. ${ }^{8}$ The area in question, Hustadvika, is characterized by shallow waters ${ }^{9}$ and the prevailing winds were pushing the vessel closer to shore. In that situation, it was decided that the ship had to be evacuated. With more than 1370 persons on board, this quickly became 'the largest public-private helicopter rescue in Norwegian history'10 as six helicopters in 30 flights evacuated almost 5 oo people in 18 hours. Despite hundreds of volunteers arriving within hours and a relatively good rescue infrastructure (due to the geographical location of the event, approx. $50 \mathrm{~km}$ each from the towns of Kristiansund and Molde and in an area with a significant offshore industry $\left.{ }^{11}\right)$. That just over a third of the persons on board could be evacuated despite good conditions has caused concerns.

In the wake of the incident, the Arctic Council's Emergency Prevention, Preparedness and Response (EPPR) Working Group discussed the hypothetical consequences and challenges if such an incident were to happen in the Arctic, for example off the coast of Svalbard. ${ }^{12}$ In light of the Arctic cruise tourism's current "superboom" and the large number of passengers on board modern cruise ships, it is clear that almost no place in the Arctic has the infrastructure which would be necessary to evacuate thousands of persons from a ship

8 EPPR, Press Release, 'The Viking Sky incident: A warning about what to expect in the Arctic', High North News (26 August 2019) <https://www.highnorthnews.com/en/ viking-sky-incident-warning-about-what-expect-arctic $>$.

$9 \quad$ Ibid.

10 Ibid.

11 Ibid.

12 Ibid. 
hundreds of kilometers from the coast on short notice. ${ }^{13}$ This problem also includes a lack of local volunteers. ${ }^{14}$ The 'EPPR is responsible for maintaining the operational guidelines of the MOSPA Agreement and ensuring implementation of the SAR Agreement, both of which are legally binding agreements negotiated under the auspices of the Arctic Council and regularly simulates incidents that exercise the worst case scenarios - improving emergency preparedness and response. ${ }^{\prime} 5$

Given the number of persons affected by a cruise ship disaster, these scenarios are among the greatest challenges for DRR in polar regions. Indeed, maritime safety law has its origins in an Arctic shipping disaster, the 1912 sinking of the Titanic, which eventually led to the development of the standards which are included in the International Convention for the Safety of Life at Sea (solas). ${ }^{16}$ Together with International Convention for the Prevention of Pollution from Ships (MARPOL), ${ }^{17}$ SOLAs forms the basis for the Polar Code, ${ }^{18}$ namely the Imo's International Code for Ships Operating in Polar Waters, covering the design, construction, equipment, operational, training, search and rescue and environmental protection issues relevant to ships operating in the Poles, which entered into force on 1 January 2017. While the entry into force of the Polar Code has been a landmark development for maritime DRR in the Arctic and off the coast of Antarctica, maritime safety law is not static and continues to be developed further. Fora like the EPPR or the International Maritime Organization, but also industry associations (such as IAATO and AECO) will continue to develop hard and soft law norms aimed at reducing the risk of disasters in polar waters. While 2019 might have seen limited legislative action, Polar Disaster Law remains a work in progress.

It has to be noted, though, that the work of entities such as AECO and IAATO does not cover a recent trend in polar tourism: individual tourism. Many tourists who visit the High Arctic and especially Antarctica come with a group of tourists, for example on a cruise ship. In the European High North, the easy

\footnotetext{
13 Cf. ibid.

14 Ibid.

15 Ibid.

16 International Convention for the Safety of Life at Sea (1974), <https://treaties.un.org/doc/ Publication/UNTS/Volume\%201184/volume-1184-I-18961-English.pdf>.

17 Protocol of 1978 relating to the International Convention for the prevention of pollution from ships (1973) (with annexes, final act and International Convention of 1973), <https:// treaties.un.org/doc/Publication/UNTS/Volume\%201340/volume-134O-A-22484-English .pdf $>$.

18 International Code for Ships Operating in Polar Waters (Polar Code, 2014), ME PC 68/21/ Add.1, Annex 10, <http://www.imo.org/en/MediaCentre/HotTopics/polar/Documents/ POLAR\%2OCODE\%2OTEXT\%2OAS\%2OADOPTED.pdf >.
} 
accessibility by airplane has long allowed for individual tourism as well. This can result in new safety challenges which are currently not yet been addressed adequately in all locations. Often, there is a presumption that a person who voluntarily enters an area is aware of the risks which exist there. The rise in car accidents involving rental cars in Iceland, which coincided with the tourism boom there, raises questions as to how the risk of accidents can be reduced in a legal and non-discriminatory manner. In addition, individual yacht tourism has been booming (albeit on a relatively low level) in particular in the Canadian Arctic. The increasing accessibility of remote areas for individual tourists or self-organized visitors, as opposed to larger tour groups, will require a new way of thinking about disaster risk reduction in polar regions, especially in the Arctic, taking into account different dimensions of safety as well as personal freedom and responsibility. 